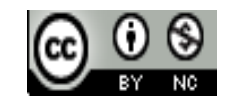

Journal of Education, Teaching and Learning is licensed under A Creative Commons Attribution-Non Commercial 4.0 International License

\title{
The EFFect Of CLT Method ON STUdents' SPEAKIng SKILL At THE SECOND GRADE OF MTSN 1 KOLAKA
}

\author{
Zakaria $^{1)}$, Rani Royani ${ }^{2)}$ \\ 1) Universitas Sembilanbelas November Kolaka, Kolaka, Indonesia \\ E-mail: alimuddin.roslina81@gmail.com \\ ${ }^{2)}$ Universitas Sembilanbelas November Kolaka, Kolaka, Indonesia \\ E-mail: rani_199349@yahoo.com
}

\begin{abstract}
This research presented about the effect of CLT Method on Students' Speaking Skill at the Second Grade of MTsN 1 Kolaka. The research question was "is there significant effect of CLT Method on Students' Speaking Skill at the Second Grade of MTsN 1 Kolaka?" The objective was to find out the effect of CLT method, the data and information about students' speaking skill at the second grade of MTsN 1 Kolaka. The design of this research was quasy expriment in two classes with pre-test and post-test design. The sample were class VIII MTsN 1 Kolaka of 208 students and took 54 students as the sample. The instruments were speaking test comprehension. Data collection techniques in this research were giving pre-test, treatment, and post-test. The result it was found that in expriment class the mean score of pre-test $(52,2)$ was smaller than the mean score of post-test $(62,6)$ it means that the increased of the students' speaking SKILL was $37 \%(0,51)$ and the value of $t_{\text {test }}$ was bigger than $t_{\text {tabel }}$ at the significant level 0,05 and degree of freedom -26 , it means that $H_{0}$ was rejected and $\mathrm{H}_{1}$ was accepted. It can concluded that there was an effect of CLT method on students' speaking skill at the second grade of MTsN 1 Kolaka.
\end{abstract}

Keywords: Communictaive language teaching, speaking skill

\section{INTRODUCTION}

The problem of teaching English to students, especially the problem of oral communication has not yet solved, and one can find much to explore in this field. Because significant role of speaking, Bailey (2005) and Goh (2007) in Yulia Morozova (2013) have proposed methods to enhance speaking skills by means of syllabus design, teaching principle, types of tasks and materials, and speaking assesment. The ways to enhance speaking skills students influence in methods of teaching by teacher.

On $21^{\text {th }}$ July 2017 the interview was held by asking the English teacher (Irma Kusmianti. S.Pd.) some questions. In this interview, the teacher admitted that, the students speaking ability at class VIII cintad amai is the lowest among class VIII rendah hati of MTsN 1 Kolaka. The teacher also said that she always combine the method in teaching speaking; she usually ask the students to read a story from their handbook and perform the text orally and askthe students to speak English in classroom when the English subject ongoing. In interaction of learning several students stay focus but still there are many students are buzy with them friends to joke, its mean the students uninterested or bored with the strategies or methods to extend the materials of learning, some problems in speaking
English, they are: the students could not speak English fluently, the students are afraid to speak in front of the classroom, and they also feel shy because laugh by his or her friend because making mistakes in speaking English.

From in the fact, based on the some problems that make student seldom speak English on their interaction of learning, the researcher has tried to imply Communicative Language Teaching approach in enhance students' speaking skill. Richard and Rodger (1999) in Dedi (2012) stated communicative approach in leanguage teaching starts from a theory of language as communication. The goal of language teaching is to develop communicative competence.

\section{REVIEW OF RELATED LITERATURE}

This chapter presents some literatures that support this research. They are: definition of speaking, problem in speaking, the goal of teaching speaking, the type of speaking activity, definition of CLT, advantages of CLT, disadvantages of CLT, characteristics and principles of CLT.

\section{A. Definition of Speaking}

Kushartanti (2005) in Ulviana (2011) states speaking as set of voices uttered by one and understood by someone else. It means to deliver thought or opinion. While, Flores (1991) 
states speaking as an interactive process of constructing meaning involves producing, receiving and processing information.

\section{B. Problem in Speaking}

Ahmad (2006) in Dwijayanti (2013) states that motivation, self-confidence, anxiety are categorized as effective variables and related to the success in second language acquisition. It has been confirmed by research over last decade and concludes these three categories as follow:

a. Motivation. Performers with high motivation generally do better in second language acquisition (usually, but not always).

b. Self confidence. Performers with self-confidence and good self-image tend to do better in second language acquisition.

c. Anxiety. Low anxiety appears to be conducive to second language acquisition. Whether measured as personal or classroom anxiety.

Therefore it can be concluded that affective factor play an important role in language learning generally for learner who are shy, guilt, fear of making mistake because those can causes embarrassment in speaking activity.

\section{The Goal of Teaching Speaking}

Scriviner (2005) states fluency and confidance are the important goals in the speaking skill. Richard (2002) in Hayati (2011) describes the concept of fluency reflects the assumption the speakers set out to produce discourse that is comprehensible, easy to follow, and free from erros and breakdowns in communication, though this goal in often not met due to processing and production demand.

Harmer (2007) states there are three main reasons for getting students to speak in the classroom. Firstly, speaking activities provide rehearsal opportunities. Secondly, speaking task in which students try to use any or all of the language they know provide feedback for both teacher and students. Finally, the more students have opportunities to activate the various elemants become.

\section{Defenition of CLT}

Jeremy in Siti (2014) a major stand of Communicative language teaching centres around essential belief that if the students are involved in mening-focused communicative tasks, then language learning will take care of itself, and that plentiful exposure to language in use and plenty of opportunities to use it are vitally important for students development of knowledge and skill.

\section{E. Advantage and Disadvantage of CLT}

Advantage of CLT, Mekhafi and Ramani (2011) in Ashraf (2014) conducted a research to investigate EFL teachers' attitudes towards using the communicative approach to the teaching of English in an EFL context. From the results of the questionnaires distributed to the participants of the study, it was found that 58 percent of them agreed that communicative language teaching produces fluent but inaccurate learners. So, communicative language teaching can follow methods like the direct method and audio lingual method in teaching grammar to focus on accuracy apart from fluency. However, concentrating on grammar and form in communicative language teaching can be different from the two mentioned methods in the way that grammar can be focused and practiced in real communication instead of practicing grammar repetitively (Brown, 2001) in individualized sentences as practiced in audio lingual method. The teacher can supervise the learners who are practicing effective communication and inform them of their grammatical errors thus enabling them to be fluent as well as accurate. Hence, both accuracy and fluency will be taken into almost equal consideration in a communicative language teaching class.

Disadvantage to be pointed out about communicative language teaching is that it is difficult to be implemented in an EFL context or classroom (Chau \& Chung, 1987; Burnaby \& Sun, 1989). Burnaby (1989) and Chau (1987) pointed out in their articles that applying communicative language teaching is difficult in an EFL context due to the lack of sources and equipment like authentic materials and native speaker teachers as well as large size of the classes. In EFL classes, the classroom is the only place that the learners receive input to learn how to conduct effective communication. Since the mother tongue is also used to manage EFL classes, the environment cannot be motivating enough to enhance communication skills of the learners. In addition, lack of native speaker teachers in EFL contexts leads to low-quality input and unauthentic material. Thus, implementing communicative language teaching in an EFL context turns to be difficult and challenging both for the teacher and the learner.

\section{F. Characteristic and Principles of CLT}

The communicative approach to language teaching is, relatively, a newly adapted approach in the area foreign/second language teaching. Wright (2000) in Ashraf (2014) Communicative language teaching is a "hybrid approach to langauge teaching, essentially 'progressive' rather than 'traditional"'. Communicative language teaching can be seen to drivefrom a multidisciplinary perspective that includes, at least, linguistics, psychology, philosophy, sociology and educational research (Savignon, 1991, in Ashraf 2014).

\section{G. Several Techniques in CLT}

Sevevral techniques in communicative language teaching there are many effectiveness techniques in communicative language teaching to improv students' speaking skill, as in Larsen and Freeman (2000) they described many techniques and materials. These are authentic materials, scrambles sentences, language game, picture strip story, and role plays.

\section{METHODOLOGY OF THE RESEARCH}

This chapter presents the methodology of the research includes the design of the research, variable of the research, 
population and sample, technique of data collection, and instrument of the research.

\section{A. Design of the Research}

The designed of the research was Quasi experiment by applied Pre-test and Post-test design. According to Sugiono (2009), the quasi experiment design is a research which is aim at discovering the influence of particular treatment. Furthermore, the quasi experiment design attempts to fulfill standards of the true experimental design as closely as possible (Hatch \& Farhady, (1982). Title and Author Details.

\section{B. Variable of the Research}

In conducted this research, the researcher has classified the variable of the research into two variables which was used in this research, they were :

Variable $\mathrm{X}$ : The effect of communicative language teaching method as the independent variable

Variable Y : Students' speaking skill as dependent variable.

\section{Population and Sample}

\section{Population}

The population of the research is all of the students at the second grade of MTsN 1 Kolaka who are registered in academic 2017/2018 year. The total of the population is 208 students and they are distributed into seven classes. The distribution of the students and this classes can be seen in the following table:

\section{Sample}

Sample is a part of population using certain procedure. So, it can be expected to represent the population. Arikunto (2006) stated that sample is a part of research population. In taking sample, the researcher used purposive sampling technique. It means that in determining the sample of the class it will be based on the purpose of the research and the interested of the researcher herself which is recommended by the English teacher.

\section{Technique of Data Collection}

In collecting the data, the researcher used the following procedures, they were:

1. Pre-test

The researhcer has distributed the pre-test in both of the classes has found out the students' prior knowledge of speaking competence before conducting the treatment.

The data acollectors were trained for data collection. Each data colector collected data from two classes which the same question test between control and experiment class.

\section{Treatment}

During the treatment, the researcher has taught the students by used Communicative language teaching method at the experiment class and conventional method at the control class in teaching speaking.

a. Experimet Class
- The teacher presented the material about simple monologue descriptive text to the students.

- The teacher devided the students into five group.

- The teacher explained about the material to the students.

- The teacher asked the leader of each group to present aboout the material.

- The teacher asked the students to investigated by comprehend and disscussed to her or him friends for some minutes.

- The teacher given apportunity to the students who have question for every group have peresnted theirs material.

- The students discussed the questions and problems related to task or text.

- The teacher monitor the class discussion.

- Every student presented their answer.

- The teacher given feedback to students who given the question.

- The teacher conluded the lesson.

b. Control Class

- The teacher presented the material about simple monologue descriptive text to the students.

- The teacher asked to the students to investigated the material for some minutes.

- The teacher given some questions and problem related to the text.

- Every students presented theirs answer.

- The teacher given feedback nd concluded the lesson.

3. Post-test

The post-test was distributed at the last meeting of the research. The data collectors were trained for data collection, each data collector collected the data from two classes. The teacher given question test related with the material werr being during treatment which the control and ecperiment class got the same question test.

\section{E. Instrument of the Research}

\section{Research Instrument}

In this research, the instrument used to be collect the data was a speaking comprehension test. The researcher has designed the difference instruments for both of pre-test and post-test. The instrument is in the form speaking test which were taken in some resources. Speaking test has used to evaluate the students' speaking ability in the form of performing simple monologue descriptive text. While, observation sheets used to observed the students' activity during teaching learning process.

\section{FINDING AND DISCUSSION}

This chapter consists of the researcher presents the findings of the research the statistical data of experimentaland contol 
class, the inferential analysis describes the analysis of the pretest and the post-test, hypothesis analysis and discussion.

\section{A. The Statistical Data of Students'Pre-test and Post-test of Control Class}

TABLE I

ONE-SAMPLE KOLMOGOROV SMIRNOV TEST

\begin{tabular}{llrr}
\hline & & Pretest & Posttest \\
\hline $\mathrm{N}$ & & 27 & 27 \\
Normal & Mean & 55,1852 & 58,5556 \\
Parameters & Std. Deviation & 11,68509 & 10,34532 \\
& Absolute &, 123 &, 112 \\
Most Extreme & Positive &, 102 &, 097 \\
Differences & Negative &,- 123 &,- 112 \\
& Kolmogorov-Smirnov Z &, 641 &, 582 \\
Asymp. Sig. (2-tailed) &, 806 &, 888 \\
\hline
\end{tabular}

Based on the normality data above it showed that significance value was 0,80 in pre-test and 0,88 in post-test bigger than 0,05 . It means that the test distribution was normal. So, the result of students' pre-test and post-test can be accepted.

\section{B. The Statistical Data of Students' Pre-test and Post-test of Experimental Class}

TABLE III

ONE-SAMPLE KOLMOGOROV SMIRNOV TEST

\begin{tabular}{|c|c|c|c|}
\hline & & Pretest & Postest \\
\hline $\mathrm{N}$ & & 27 & 27 \\
\hline Normal & Mean & 52,2222 & 62,6296 \\
\hline b & Std. Deviation & 11,41636 & 10,01210 \\
\hline Most & Absolute & , 158 &, 150 \\
\hline Extreme & Positive &, 158 & ,082 \\
\hline Differences & Negative &,- 145 &,- 150 \\
\hline Kolmogorov & Smirnov Z & ,820 & ,781 \\
\hline Asymp. Sig. & (2-tailed) & ,512 &, 576 \\
\hline
\end{tabular}

Based on the normality data above it showed that significance value was 0,51 in pre-test and 0,57 in post-test bigger than 0,05 . It means yhat the test distribution was normal. So, the result of students' pre-test and post-test can be accepted.

\section{Hypothesis Testing}

Hyphothesis testing used to investigated whether there is an effect of using Communicative Language Teaching (CLT) method on students' speaking competence at the second grade of MTs Negeri 1 Kolaka. To find out the degree of freedom (Df) the researcher used the formula $\mathrm{Df}=\mathrm{N}-1$, where $\mathrm{N}=27$, so $\mathrm{Df}=27-1=26$ at the significant level $(\alpha) 0,05$. Based on the result of testing hypothesis shows $t_{\text {count }}$ was higher thent $t_{\text {table, }}$, this indicated that $\mathrm{H}_{1}$ was accepted and $\mathrm{H}_{0}$ was rejected which means that there is an effect of Communicative Language Teaching (CLT) method on students' speaking competence at the second grade of MTs Negeri 1 Kolaka.

TABLE IIIII

HYPOTHESIS TESTING OF EXPERIMENTAL CLASS

\begin{tabular}{ccccc}
\hline Df & $\begin{array}{c}\text { Statistic } \\
\mathbf{t}_{\text {table }}\end{array}$ & $\mathbf{t}_{\text {count }}$ & & Result \\
\cline { 1 - 1 } & & & & $\begin{array}{c}\mathbf{t}_{\text {count }}>\mathbf{t}_{\text {table }} \\
\mathbf{H}_{0}= \\
\text { Rejected } \\
\mathbf{H}_{1}= \\
\text { Accepted }\end{array}$ \\
\end{tabular}

\section{Discussion}

The result of the students' speaking test in evaluation showed that there was an effect on the students' speaking skill in term of fluency from pre-test to post-test after being treated communicative language teaching (clt). It could be proven by looking the mean score and the percentage of students' success tfrom speaking test in pre-test and post-tes. Inpre-tes, there are only 4 students of 27 students get score $\geq 66$. Thus, the mean score is 52,2 and the percentage of students' success is $15 \%$. In cycle two, the mean score increased 10,4 and the percentage of students' success increase $37 \%$. Where there are 13 of 27 students get score $\geq 66$. Therefore, the mean score is 62,6 and the percentage of students' success was $52 \%$.

\section{CONCLUSIONS}

Referring to the result of this research, it was obvious that communicative language teaching (CLT) method was contributed positive effect toward the students' speaking ability result. From the result comparison between the pre-test and post-test of experimental class, it was indicate that the post-test of experimental class was found to be higher $(52,2)$ than the pre-test $(62,2)$, meaning that there was improvement in achievement after treatment. In addition to this, another statistical calculation results of the post-test comparison between experimental and control class showed that experimental class had performed better than control class. This was indicated by the means of the experimental class which was higher $(62,2)$ than that of the control class $(58,5)$. 
In addition, the result also can be seen from $\mathrm{T}$-test in the significant level $(\alpha)$ of 0,05 . The result showed that T-test $\left(\mathrm{T}_{\text {count }}\right)>\mathrm{T}$-table $\left(\mathrm{T}_{\mathrm{t}}\right)(62,62>55,22)$. It means that that $\mathrm{T}$-test was higher in the value (3.0890) than T-table. So, the null hypothesis (Ho) was rejected. It means that alternative hypothesis (Ha) was accepted that there was a significant effect of using communicative language teaching (CLT) method on student's speaking skill at the second grade of MTs Negeri 1 Kolaka.

\section{ACKNOWLEDGMENT}

We would like to thank Causal Productions for permits to use and revise the template provided by Causal Productions. Original version of this template was provided by courtesy of Causal Productions (www.causalproductions.com).

\section{REFERENCES}

Arikunto. (2006). Prosedur Penelitian Suatu Pendekatan Praktek. Jakarta: Rineka Cipta.

Arikunto. (2006). Pengantar Statistika Pendidikan. Jakarta: Rajawali Pers.

Bashir, Marriam. (2011). Factor Effecting Sudents' English speaking skill. Pakistan: British Jurnal of Arts and Social Sciences.

Darn, Steve. (2008). Graphic Organizers. Online. Available: www.stevedarn.com.

Efrisal, Dedi. (2012). Improving Student' English Through Communicative Language Teaching Method. Bengkulu: International Jurnal of Humanities and Social Sciene.

Flores. (1991). Communication Language Teaching: The State of Art. (Tesol, Quarterly)

Harmer, Jeremy. (1996). How to Teach English. London: Addison Wesley Longman

Hornby. (1974). Advanced Learner Dictionary of Current English. New York: Oxford University Press.

http://www.jstor.org/pss/1476834

http://dx.doi.org/10.5539/elt.v5n12p87

Indra, Galih. (2013). The Use of Mind Mapping Strategy to Improve Stuudents' Ability in Writing Procedure Text. Thesis.English Department of Semarang State University

Johnson, David W., Johnson, Roger T. (1991). Cooperativelearning: Increasing College Faculty Instructional Productivity. ASHE-ERIC Report on Higher Education. Washington, DC: The George Washington University.

Krashen, S.D. T. (1983). The Natural Approach: Language Acquisition in the Classroom.Pergamon.

Littelwood, W. (1981).Communicative Language Teaching: an Introduction. Cambridge. Cambridge University Press.

McDonough and Christopher, Shaw. 1993. Material and Method in ELT: A Teacher Guide. Cambridge: Blackwell Publisher.

Nurhayati, Siti. (2011). Teaching Speaking Skill Trough Communicative Language Teaching. Thesis.English
Department of Syarif Hidayatullah State Islamic University Jakarta.

Oxford University Press. (2006). Oxford Advanced Learner's Dictionary $7^{\text {th }}$ Edition. New York: Oxford University Press.

Richards, Jack C. (2006). Communicative Language Teaching Today.Cambridge. Cambridge University Press.

Richard, Jack C and Rodgers, Theodore. (1986). Approaches and Methods in Language Teaching.Cambridge: Cambridge University Press.

Richeit, Gert and Strohner, Hans. (2008). Handbook of Communication Competence. Germany.

Sreehari, Pusuluri. (2012). Communicative Language Teaching: Possibilities and Problems. Saudi Arabia. Department of English Al Jouf University. Canadian Centre of Since and Education.

Sudjana. (1996). Metode Statistika. Bandung: Tarsito

Sudijono, Anas. (2008). Pengantar Statistika Pendidikan. Jakarta: PT. Raja Grafindo Persada.

Sugiyono. (2010). Statistika untuk Penelitian. Bandung: Penerbit Alfabeta

Ur, P. (1996). A Course in Language Teaching: Practice and Theory. United Kingdom: Cambridge University

www.dictionary.reference.com. Retrieved on Wednesday, $26^{\text {th }}$ August 2015

Verhaar.J.W.M. (2001). Asas-asas Linguistik Umum (cetakan ketiga). Yogyakarta: Gadjah Mada University Press. 